\title{
An Evaluation of the Sustainable Development Lever of Listed Commercial Banks in China
}

\author{
Haiying $\operatorname{Pan}^{1} \&$ Chaochao $\mathrm{Gu}^{1}$ \\ ${ }^{1}$ Business School, Hohai University, Nanjing, China \\ Correspondence: Chaochao Gu, Business School, Hohai University, Nanjing 211100, China. E-mail: \\ guchaochao1990@163.com
}

Received: May 28, 2013

Accepted: June 27, 2013

Online Published: August 8, 2013

doi:10.5430/rwe.v4n2p75

URL: http://dx.doi.org/10.5430/rwe.v4n2p75

This paper was supported by "Humanities and Social Sciences Research Planning Foundation Project of Ministry of Education” (12YJA790102).

\begin{abstract}
With the in-depth reform and innovation of commercial banks, research on the sustainable development of commercial banks has become a hot topic. This paper conducts an empirical analysis of the level of sustainable development of Chinese 16 listed banks with the factor analysis method, attaining four public factors that affect the sustainable development of commercial banks, namely profitability factor, risk control factor, development capacity factor and liquidity factor. In addition, this paper analyzes the banks' performances in four factors and their ranking of the sustainable development lever. At last, this paper proposes recommendations from the four aspects for the sustainable development of commercial banks.
\end{abstract}

Keywords: listed commercial banks, sustainable development lever, factor analysis

\section{Introduction}

Sustainable development is an economic growth mode emphasizing long-term development. It not only aims at meeting the needs of contemporary people, but also doing no harm to meet the future generations' needs. With the in-depth research and the growth of financial sustainable development theory, the issue of sustainable development of commercial banks has get people's attention gradually. Facing the complexity of external environment and the uncertainty of economic trends, in addition to the requirement of speeding up transformation of economic development modes from the '12th Five-Year Plan', the development of Chinese commercial banks is in need of reform and innovation, while the evaluation of sustainable development of commercial banks has great significance for the reform and innovation.

In recent years, some scholars at home or abroad have developed discussions concerning sustainable development of commercial banks. There are no micro commercial banks and rural commercial banks abroad, therefore, research on the sustainable development is impossible, but scholars have developed in-depth study on the sustainable development of microfinance, considering that the best mode for micro financial industry development is to seek sustainable development. Vinelli (2002) explained in detail, in which, "sustainability could bring the expansion of microfinance institutions' funding sources", "consideration about sustainability issues makes microfinance institutions to focus on cost control". Gary Woller (2002) showed that, the performance of microfinance institutions is positively associated with market orientation, and we can promote the sustainable development of microfinance industry from the perspective of marketing management. The world bank's Ajai Nair (2005) concluded that the SHG alliance scale economic effect can reduce the transaction costs and the default rate, so as to ensure the sustainability of SHG. J. Jordan Pollinger et al (2007) analyzed America microfinance practice and the operation mode of micro credit, drawing the conclusions that the actual price of America MFI loans below the equilibrium price affects its long-term sustainable development, making suggestions to improve the sustainability of microfinance institutions from the pricing mechanism.

How to promote the sustainable development of commercial banks, has been the research focus of Chinese scholars. Qi et al (2000) analyze the impact of external environment changes to commercial banks from the four aspects including national policy, enterprise customer, market structure and competition, drawing the conclusions that 
commercial banks should actively adapt to the changes from external environment in order to achieve sustainable development. Qiu (2002) concludes that the sustainable development of commercial banks should be based on the effective use of financial resources. $\mathrm{Li}$ (2002) proposed that the financial product innovation has an important strategic significance for the sustainable development of commercial banks, it will become the driving force for the sustainable development of commercial banks. Sun (2004) thought that commercial banks should skillfully use the modern marketing theory to guide the actual work, so as to seek their own survival and development. Ma (2006) put forward the establishment of effective corporate governance structure, to overcome the high non-performing assets of state-owned commercial banks. Suo et al (2009) considered that commercial banks must strengthen the financial innovation to be sustained, steady development. Except for the development of new business space and profits creation for banks, the financial innovation also leads to new risks, therefore the current reform of the banking industry must seek a proper balance between financial innovation and risk management.

Only a few studies were carried out on the measure and evaluation of the sustainable development of commercial banks. He (2005) measures whether the banking development has the support of economic competitiveness by comparing the actual growth rate of bank credit supply and demand, and then evaluates the sustainability development of banks. Wei (2008) analyzed the ability of sustainable development of commercial banks based on the economic evaluation methods of commercial bank efficiency analysis. Li (2012) constructs the evaluation index system of sustainable development of commercial banks based on the financial sustainable development theory, and analyzes empirically the sustainable development ability of four state-owned commercial banks.

At present, the studies on the sustainable development of the banking industry are still relatively few, just qualitative and simple quantitative analysis. Taking Chinese 16 listed commercial banks as samples, this paper analyzes empirically the level of sustainable development of listed banks using factor analysis method, concluding the influencing factors of the sustainable development of commercial banks. According to the result of the research, we put forward relevant recommendations from the view of the features of sustainable development of commercial banks.

\section{Indicators, Data and Methodology}

\subsection{Indicators Selection and Data Collection}

Drawing on previous researches on the sustainable development of commercial banks, as well as indicator representation and data availability, this paper selects the following 15 measurement indicators: operating income $\left(\mathrm{X}_{1}\right)$, operating profit $\left(\mathrm{X}_{2}\right)$, total profit $\left(\mathrm{X}_{3}\right)$, net profit $\left(\mathrm{X}_{4}\right)$, total assets $\left(\mathrm{X}_{5}\right)$, total liabilities $\left(\mathrm{X}_{6}\right)$, the owner's equity $\left(X_{7}\right)$, profit growth rate $\left(X_{8}\right)$, asset growth rate $\left(X_{9}\right)$, rate of return on total assets $\left(X_{10}\right)$, net assets per share $\left(X_{11}\right)$, the capital adequacy ratio $\left(\mathrm{X}_{12}\right)$, the core capital adequacy ratio $\left(\mathrm{X}_{13}\right)$, liquidity ratio $\left(\mathrm{X}_{14}\right)$, loan-to-deposit ratio $\left(\mathrm{X}_{15}\right)$.

The paper takes the annual report data from Chinese 16 listed banks in 2011 as research object. During data processing, the indicator of $\mathrm{X}_{14}$ is the appropriate indicator, the liquidity indicator nationally recognized a minimum of $25 \%$, so we deal with indicator $X_{14}$ as follows: $X_{14}^{\prime}=X_{14}-25 \%$.

\subsection{Methodology}

This paper uses the factor analysis method to analyze the level of sustainable development of listed banks. In 1931, Thurstone first proposed the name of factor analysis, but virtually, the concept originated from a statistical analysis of an intelligence test by Karl Pearson, Charles Spearmen and other scholars at the beginning of twentieth century. Factor analysis is a multivariate statistic analysis method, which investigates through the internal dependencies of correlation matrix, summing up a few representative synthetic factors from the numerous complex variables.

The basic thought of factor analysis is to classify the original variables according to the lever of variable correlation. It enables correlation among variables in the class to be higher, while the correlation between different classes is low, then the variables in each class represent a basic structure type, that is the public factor. These factors can reflect the main information contained in the original variables, making the analysis simpler, more intuitive and effective. Usually this method draws the factor structure and factor score model. The former reflects the relationship between the indicator and the public factor via correlation coefficient, while the latter expresses the public factors as a linear combination of the original indicator with the form of regression equation. Finally the comprehensive scores can be calculated.

The advantage of factor analysis is that the determination of each public factor's weight is based on variance contribution rate. The larger the variance is, the more important the variable is, that means it gets a larger weight; accordingly, the smaller the variance is, the smaller weight it gets. This avoids the subjectivity and randomness of determining weights, which makes the evaluation results effective and objective. 


\section{Empirical Results and Analysis}

\subsection{Factor Analysis Process}

\subsubsection{Data Standardization and Correlation Test}

Before factor analysis, in order to avoid the effect of different dimensions upon determining public factors, standardize the original data is firstly needed, thus, the difference between every variable value and sample mean should be divided by the standard deviations of samples, the formula (1) is shown as follows. After putting the original data into the formula below, we get the standardized indicator data of each listed banks.

$$
\text { Zscore }: z_{i}=\frac{x_{i}-\bar{x}}{s}
$$

Another important precondition for factor analysis is that strong correlation is required among the original variables. If there is no strong correlation between two original variables, public factor can not be found. Therefore, before analyzing the data, we should test the correlation. With the standardize data of commercial banks analyzed by SPSS software, we get the correlation coefficient matrix, it is observed that most correlation coefficient are greater than 0.3 , all variables showed a strong linear relationship, that is to say, public factors could be extracted from them. In addition, the KMO value is 0.741 , Bartlett sphericity test statistic is 651.31 , and the corresponding probability of Sig. is 0.000 . It is considered that correlation matrix and unit matrix has a remarkable difference, which is suitable for factor analysis.

\subsubsection{Public Factor Extraction}

We select the factor analysis method to extract public factor. Table 1 shows that the first four factors' characteristic value are greater than 1.0, and the first four factors' sum of the variance accounts for $85.946 \%$ of the overall sample variance. On the whole, the four factors reflect most of the information of original variables, and the factor analysis result is ideal.

Table 1. Factor characteristic value, variance contribution rate and cumulative variance contribution rate

\begin{tabular}{|c|c|c|c|c|c|c|c|c|c|}
\hline \multirow{2}{*}{ component } & \multicolumn{3}{|c|}{ Initial characteristic value } & \multicolumn{3}{|c|}{$\begin{array}{c}\text { Load of extraction sum of } \\
\text { squares }\end{array}$} & \multicolumn{3}{|c|}{$\begin{array}{c}\text { Load of rotation sum of } \\
\text { squares }\end{array}$} \\
\hline & total & $\begin{array}{l}\text { varian } \\
\text { ce } \% \\
\end{array}$ & $\begin{array}{l}\text { accumulat } \\
\text { ion } \%\end{array}$ & total & $\begin{array}{l}\text { varian } \\
\text { ce } \%\end{array}$ & $\begin{array}{l}\text { accumulat } \\
\text { ion } \% \\
\end{array}$ & total & $\begin{array}{l}\text { varian } \\
\text { ce } \%\end{array}$ & $\begin{array}{l}\text { accumulat } \\
\text { ion } \% \\
\end{array}$ \\
\hline \multirow{2}{*}{1} & 7.76 & 51.7 & 51753 & 7.76 & 51.7 & \multirow{2}{*}{51.753} & 7.15 & 47.7 & \multirow{2}{*}{47.713} \\
\hline & 3 & 53 & 51.153 & 3 & 53 & & 7 & 13 & \\
\hline \multirow{2}{*}{2} & 2.8 & 18.9 & 70746 & 2.84 & 18.9 & \multirow{2}{*}{70.746} & 2.36 & 15.7 & \multirow{2}{*}{63.472} \\
\hline & 49 & 93 & 10.140 & 9 & 93 & & 4 & 59 & \\
\hline \multirow{2}{*}{3} & 1.2 & 8.50 & & 1.27 & 8.50 & \multirow{2}{*}{79.249} & 2.04 & 13.6 & \multirow{2}{*}{77.115} \\
\hline & 75 & 3 & 19.249 & 5 & 3 & & 7 & 44 & \\
\hline \multirow{2}{*}{4} & 1.00 & 6.69 & 85946 & 1.00 & 6.69 & \multirow{2}{*}{85.946} & 1.32 & 8.83 & \multirow{2}{*}{85.946} \\
\hline & 5 & 7 & 85.940 & 5 & 7 & & 5 & 1 & \\
\hline
\end{tabular}

According to Figure 1, the first factor's characteristic value is very high, indicating that it makes the greatest contribution to the interpretation of original variables. The factor's characteristic value after the fourth is smaller, so its contribution to the original variable's interpretation is less, which means, they can be ignored, so it is appropriate to extract the first four factors.

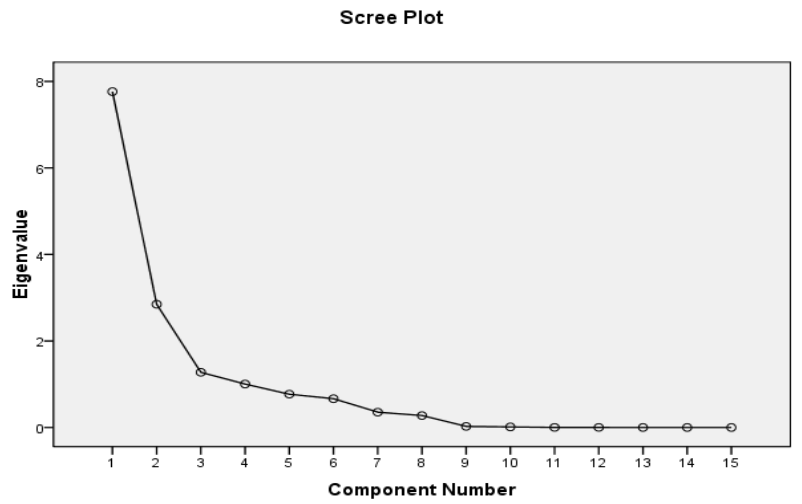

Figure 1. Scree plot 


\subsubsection{Factor Explanation}

After extracting initial factors, we find that they can not be explained effectively. In order to explain the factor preferably, loading matrix rotation is need. Rotation aims to change every variable load capacity of each factor. The rotated component matrix is as shown in Table 2 after varimax orthogonal rotation.

Table 2. Rotation component matrix

\begin{tabular}{lcccc}
\hline & \multicolumn{4}{c}{ Component } \\
& 1 & 2 & 3 & 4 \\
\hline $\mathrm{X}_{1}$ (operating income) & 0.982 & -0.010 & 0.171 & 0.027 \\
$\mathrm{X}_{2}$ (operating profit) & 0.985 & -0.004 & 0.143 & 0.026 \\
$\mathrm{X}_{3}$ (total profit) & 0.985 & -0.001 & 0.144 & 0.029 \\
$\mathrm{X}_{4}$ (net profit) & 0.983 & 0.007 & 0.151 & 0.031 \\
$\mathrm{X}_{5}$ (total assets) & 0.981 & -0.014 & 0.184 & 0.002 \\
$\mathrm{X}_{6}$ (total liabilities) & 0.981 & -0.016 & 0.180 & -0.001 \\
$\mathrm{X}_{7}$ (owner's equity) & 0.966 & 0.015 & 0.244 & 0.049 \\
$\mathrm{X}_{8}$ (profit growth rate) & 0.237 & -0.201 & 0.602 & 0.117 \\
$\mathrm{X}_{9}$ (asset growth rate) & 0.094 & -0.218 & 0.806 & -0.255 \\
$\mathrm{X}_{10}$ (rate of return on total assets) & -0.469 & 0.102 & 0.357 & 0.275 \\
$\mathrm{X}_{11}$ (net assets per share) & 0.362 & -0.024 & 0.776 & 0.094 \\
$\mathrm{X}_{12}$ (capital adequacy ratio) & 0.047 & 0.888 & -0.255 & 0.241 \\
$\mathrm{X}_{13}$ (core capital adequacy ratio) & -0.011 & 0.940 & -0.030 & 0.276 \\
X $_{14}$ (liquidity ratio) & 0.100 & 0.216 & 0.008 & 0.857 \\
$\mathrm{X}_{15}$ (loan-to-deposit ratio) & 0.047 & -0.738 & 0.286 & 0.472 \\
\hline
\end{tabular}

According to the implication of each indicator, we give each public factor a proper name as follows:

Factor 1 weights more in $\mathrm{X}_{1}, \mathrm{X}_{2}, \mathrm{X}_{3}, \mathrm{X}_{4}, \mathrm{X}_{5}, \mathrm{X}_{6}, \mathrm{X}_{7}$ indicators, representing bank's profitability and sustainable development efficiency, so we define factor 1 as profitability factor.

Factor 2 weights more in $\mathrm{X}_{12}, \mathrm{X}_{13}$ indicators, reflecting bank's risk control ability, and the stability of sustainable development at the same time. Thus, we define factor 2 as risk control factor.

Factor 3 weights more in $\mathrm{X}_{8}, \mathrm{X}_{9}, \mathrm{X}_{10}, \mathrm{X}_{11}$ indicators, basically representing bank's development ability and the continuity of sustainable development, so factor 3 is defined as development ability factor.

Factor 4 weights more in $X_{14}, X_{15}$ indicators, reflecting bank's fluidity management ability, so factor 4 can be defined as liquidity factor.

3.1.4 Factor Scores Calculation

According to the factor score coefficient matrix, we can draw the following factor score functions:

$$
\begin{gathered}
F_{1}=0.151 X_{1}+0.157 X_{2}+0.156 X_{3}+\cdots-0.048 X_{13}-0.005 X_{14}-0.012 X_{15} \\
F_{2}=-0.016 X_{1}-0.02 X_{2}-0.019 X_{3}+\cdots+0.452 X_{13}-0.005 X_{14}-0.384 X_{15} \\
F_{3}=-0.056 X_{1}-0.077 X_{2}-0.075 X_{3}+\cdots+0.209 X_{13}+0.025 X_{14}+0.012 X_{15} \\
F_{4}=0.007 X_{1}+0.006 X_{2}+0.008 X_{3}+\cdots+0.093 X_{13}+0.65 X_{14}+0.467 X_{15}
\end{gathered}
$$

Taking each factor's variance contribution rate as the weight of comprehensive evaluation, and according to the weighted sum of the four factors' variance contribution rate, we can get integrated factor score, that is the computational formula of the level of sustainable development of commercial banks, it is shown as follows:

$$
F=0.6022 F 1+0.2152 F 2+0.0989 F 3+0.0769 F 4
$$

According to calculation of SPSS software, we can obtain the scores and sequence results of 4 public factors and integrated factor of 16 listed commercial banks which are shown in Table 3. 


\subsection{Results Analysis}

According to each public factor's score, integrated factor's score and ranking shown in Table 3, we can perform evaluation and comparison for the level of sustainable development of listed banks.

Table 3. Listed banks' integrated factor score and ranking

\begin{tabular}{|c|c|c|c|c|c|c|}
\hline & F1 & $\mathrm{F} 2$ & F3 & F4 & $\mathrm{F}$ & Ranking \\
\hline Bank of China & -0.2898 & 0.0706 & -1.1232 & 0.4329 & -0.237 & 9 \\
\hline $\begin{array}{c}\text { Agricultural Bank } \\
\text { of China }\end{array}$ & -0.2484 & 0.4713 & -0.9949 & -1.4771 & -0.26 & 10 \\
\hline $\begin{array}{c}\text { China Construction } \\
\text { Bank }\end{array}$ & -0.4853 & 0.8521 & -0.7919 & 1.4118 & -0.079 & 7 \\
\hline $\begin{array}{c}\text { Industrial and } \\
\text { Commercial Bank } \\
\text { of China }\end{array}$ & -0.4225 & 0.5443 & -1.0251 & -1.1922 & -0.147 & 8 \\
\hline $\begin{array}{c}\text { China Merchants } \\
\text { Bank. }\end{array}$ & -0.4742 & -1.0159 & -0.7332 & 0.7415 & -0.519 & 13 \\
\hline China Citic Bank & -0.7526 & -0.1649 & 0.8205 & 0.4659 & -0.372 & 11 \\
\hline Huaxia Bank & 0.9692 & -0.2348 & 0.5778 & -0.5675 & 0.547 & 2 \\
\hline Industrial bank & -0.7549 & -0.7304 & 1.2300 & -0.9284 & -0.561 & 14 \\
\hline Pingan Bank & 0.4252 & -0.1329 & 2.2938 & 1.0323 & 0.534 & 3 \\
\hline $\begin{array}{l}\text { Shanghai Pudong } \\
\text { Development Bank }\end{array}$ & 3.2593 & -0.4387 & -0.5836 & 0.3502 & 1.837 & 1 \\
\hline $\begin{array}{c}\text { Bank of } \\
\text { Communications }\end{array}$ & -0.4377 & -0.4722 & -0.4884 & -0.2437 & -0.432 & 12 \\
\hline Minsheng Bank & -0.6965 & -1.3897 & 0.4063 & 0.7126 & -0.623 & 15 \\
\hline Bank of Nanjing & -0.3320 & 2.1506 & 1.0252 & -0.5136 & 0.325 & 6 \\
\hline Bank of Beijing & 0.6291 & 0.4288 & 0.5367 & -1.5721 & 0.403 & 5 \\
\hline Bank of Ningbo & 0.0029 & 1.6006 & -0.5148 & 1.6399 & 0.421 & 4 \\
\hline Everbright Bank & -0.3916 & -1.5386 & -0.6351 & -0.2926 & -0.652 & 16 \\
\hline
\end{tabular}

\subsubsection{The Public Factors' Evaluation}

It is seen from Table 3 that only 6 banks' integrated factor score are positive among 16 listed banks, indicating that the level of sustainable development of Chinese listed banks is generally low.

In terms of profitability, Shanghai Pudong Development Bank and Huaxia Bank are in the front row. It is mainly due to the higher superiority indicator of operating income, operating profit and net profit which reflect bank profitability than other banks, while China Citic Bank, Minsheng Bank, and Industrial Bank have shown poor performance in profitability.

In terms of risk control, the overall performance of Bank of Nanjing is good. Its capital adequacy ratio is 14.96\%, and core capital adequacy ratio is $11.76 \%$, that is to say, it has a certain advantage in asset security. In addition, Bank of Ningbo, Bank of Beijing and four state-owned commercial banks have performed well in this field. On the contrary, some joint-stock listed banks such as Everbright Bank, Minsheng Bank and China Citic bank are lacking in risk control management. They need to strengthen the risk prevention to ensure stability.

In aspect of development ability, Pingan Bank, Industrial Bank and Bank of Nanjing come out in front. These banks have a clear market positioning, meanwhile, they are good at seizing market opportunities, take an active attitude towards developing business, are brave in innovating and promoting new products, all of which have satisfied the diverse needs of investors. But taking a look at the scores of development ability of four state-owned commercial banks, we find disappointedly that they are negative.

In the aspect of liquidity management, the liquidity ratio of Bank of Ningbo, China Construction Bank and Pingan Bank is $52.19 \%, 53.7 \%, 51.93 \%$ respectively, far more exceeded than other commercial banks. Therefore, the scores of liquidity management ability of the three banks are optimal. While the liquidity management ability of Industrial and Commercial Bank of China, Bank of Beijing, and Agricultural Bank of China are weaker. 


\subsubsection{Analysis of Comprehensive Evaluation Result}

From the comprehensive results showed in Table 3, we find that the sustainable development level of Shanghai Pudong Development Bank, Huaxia Bank, and Pingan Bank are the highest, while Everbright Bank, Minsheng Bank and Industrial Bank remain at the bottom.

From an overall aspect, the sustainable development ability of large joint-stock commercial banks is the best, such as Shanghai Pudong Development Bank, Huaxia Bank and Pingan Bank. The reason lies in their stronger profitability when compared with other commercial banks. Although they are not dominant in risk control factor, the profitability is the main influencing factor to the level of sustainable development, so in the comprehensive view, the sustainable development capacity of them is the strongest. But there is still imperfect corporate governance in large joint-stock banks. It is need to effectively strengthen the protection of the interests of minority shareholders, strengthen the system construction, improve the mechanism of checks and balances, and inhibit financial corruption. This is an important guarantee for the sustainable development of the large joint-stock banks.

Large city commercial banks such as Bank of Ningbo, Bank of Beijing and Bank of Nanjing have a better level of sustainable development. In these banks, in addition to slightly backward in liquidity management factor, they are all performed well in the other three factors, especially in the risk control factor they keep ahead of other listed banks, so the comprehensive development level is still high. But the city commercial banks are still in the early stage of development, so the foundation is weak, naturally, they are still small-sized and medium-sized banks. They still hold a low share in the entire financial market and are lack of influence. Therefore, the large-scale city commercial banks should make efforts in taking a reasonable market position, in strengthening innovation ability, in sounding internal control mechanism in order to seize the opportunity to grow.

Four state-owned commercial banks perform badly in the sustainable development. The main reason is that four state-owned commercial banks have poor performance upon profitability and development capacity in the sustainable development evaluation system. Meanwhile, four state-owned commercial banks exist malpractices such as a large number of redundant staff, high non-performing loan ratio and low capital utilization ratio, all of which have negative impacts on the efficiency of resource allocation. Besides that, four state-owned commercial banks have maintained the originally old development mode and strategy, which has been an obstruction of business inefficient improvement, hence leads to low level of sustainable development. This has been an important issue to be solved in four state-owned commercial banks for a long time.

The level of sustainable development of small joint-stock banks is poor. The reason is that these relatively small joint-stock banks such as China Everbright Bank, Minsheng Bank and Industrial Bank have been troubled by the small scale and diseconomies of scale, which bring about the strong impulse for expansion. However, in the case of capital unchanged, the bank assets' rapid expansion always goes hand in hand with the decline of capital adequacy ratio, which means the higher the risks the bank bears, the lower the business safety degree will be. Therefore, the level of sustainable development is unsatisfactory. From the perspective of risk aversion, small joint-stock commercial banks must establish the scientific concept of development firmly and overcome the impulse of internal expansion gradually, in order to maintain an appropriate speed of asset expansion.

\section{Conclusions and Recommendations}

The four influencing factors we conclude in this paper, including profitability factor, risk control factor, development capacity factor and liquidity factor are used to describe respectively the features of efficiency, stability, continuity and coordination of sustainable development of commercial banks. From the level of sustainable development, we find that large joint-stock commercial banks perform best, followed by city commercial banks, four major state-owned commercial banks rank third, and small joint-stock banks locate at the bottom. According to the research results, we put forward the following recommendations from four aspects.

First, efficiency of the sustainable development of commercial banks refers to the ability of rational development and efficient allocation of financial resources. In respect of profitability which reflects the characteristic of efficiency, both four state-owned commercial banks and small joint-stock commercial banks perform badly, and these banks are required to put focus on reconstruction and business transformation. They should change from quantity oriented to quality-benefit, from extensive management to the intensive management. Meanwhile, they should vigorously develop various kinds of intermediate business and financial services for small and medium-sized enterprise, and create a development road with characteristic of differentiation, specialization and particularity.

Second, to strengthen risk management is the requirement of the stability of commercial banks' sustainable development. The results of this paper show that joint-stock banks such as China Everbright Bank, Minsheng Bank, and China Citic Bank behave poorly in risk control ability. So in order to improve the level of risk control ability, they need to make efforts in the following three aspects. Firmly establish the concept of risk management and create a good environment of risk management, enhance the sensitivity and foresight of risk management are first needed. 
At the same time, they should improve continuously the risk management system, improve the risk management information system. Furthermore, they should make full use of all kinds of risk identification and measurement tools, effectively identify risks, and enhance the ability to price risk so as to improve the quality of risk management.

Third, continuity of the sustainable development of commercial banks requires that commercial banks should not only take the needs of current development into consideration, but also the future development. Four state-owned commercial banks have been remained stagnant in the development mode and strategy. Therefore, they should maintain long-term competitive advantage by means of financial innovation. First of all, they should vigorously promote the management innovation system, innovate performance evaluation system, complete the salary management system, accelerate the achievement from performance appraisal to performance management, fully mobilize the enthusiasm of employees, to promote better and faster development of business. Meanwhile, they should pay more attention to product innovation. According to the change of market environment, state-owned banks should try to develop new products timely to meet market and customer needs, and strengthen the construction of product R \& D team in order to improve the product research and development ability.

Fourth and finally, it is required by the coordination of the sustainable development that commercial banks should pay more attention to the coordination and mutual development of other stakeholders when they are in the pursuit of their own interests and growth. This demands that commercial banks should actively implement green credit policy, embed environmental and social risk factors in credit risk management, increase the loans of energy-saving and emission reduction projects, innovate low carbon financial products and services, guide the capital to invest in environmental protection projects and industry, and achieve a good combination of commercial interests and environmental protection benefits. This is an important issue which Chinese commercial banks should pay attention to in order to realize the sustainable development.

\section{References}

Ajai Nair. (2005). Sustainability of Microfinance Self Help Groups in India: Would Federating Help? World Bank Policy Research Working Paper.

Du, Xiaorong, \& Zhang, Ling. (2007). Study on the Factors Affecting the Sustainable Development of Chinese Commercial Banks Based on Resources and Capabilities. Productivity Research, (19), 28-29.

He, Chang. (2005). Preliminary Assessment of Chinese Banks' Sustainable Development. Finance and Economy, (10), 22- 23.

J. Jordan Pollinger, John Outhwaite \& Hector Cordero-Guzman. (2007). The Question of sustainability for Microfinance Institutions. Journal of Small Business Management, (1), 23-41. http://dx.doi.org/10.1111/j.1540-627X.2007.00196.x

Li, Dong. (2012). Research on the Evaluation of Sustainable Development of Commercial Bank Based on Factor Analysis Method. Western Finance, (2), 59-62.

Li, Jing. (2002). Innovation ability: The Source of the Sustainable Development of Chinese Commercial Banks. Enterprise Economy, (12), 185-186.

Ma, Guoqing. (2006). Strategy Choice of the Sustainable Development of Chinese Commercial Banks. Journal of Gansu Lianhe University, (5), 41-43.

Qi, Laying, \& Hu, Chunyan. (2000). Consideration on the Sustainable Development of Commercial Banks. Journal of Wuhan College of Finance, (5), 7-11.

Qiu, Wei. (2002). View the Sustainable Development of Chinese Commercial Banks from the Theory of Financial Resources. Financial Science, (1), 20-23.

Sui, Jian, \& Pan, Lijuan. (2011). Reflections on Sustainable Development Strategy of Chinese Commercial Banks in the Post-crisis Era. Views and Points, (5), 41-45.

Suo, Yanfeng, \& Chen, Jiming. (2009). Sustainable Development of Banks: Seek a Proper Balance between Financial Innovation and Risk Management. South Finance, (11), 12-13.

Sun, Yingchun. (2004). Discussion about the Application of Modern Marketing Theory in the Sustainable Development of Commercial Banks. Journal of Changchun Finance College, (2), 23-25.

Tan, Rongbo, \& Mei, Xiaoren. (2007). SPSS Statistical Analysis and Practical Tutorial. Science Press, 202-207.

Vinelli, Andres. (2002). Financial Sustainability in U.S Organizations. Woodrow Wilson CenterPress.

Wei, Xian. (2008). Study on the Sustainable Development of Banks. Ph D Thesis of Shanghai Fudan University.

Woller Gary. (2002). From Market failure to Marketing failure: Market-orientation Asthe Key to Deep Outreach in Microfinance. Journal of International Development, (14), 305-324. 